УДК: 633,49

\title{
ВЛИЯНИЕ ЭЛЕМЕНТОВ ТЕХНОЛОГИИ ВОЗДЕЛЫВАНИЯ НА ПРОДУКТИВНОСТЬ И КАЧЕСТВО КАРТОФЕЛЯ
}

\author{
Абидова Галимат Хабаловна \\ аспирант \\ Абидов Азамат Хасетович \\ аспирант \\ Одижев Андемиркан Арсеанович \\ аспирант \\ Тутов Аскерби Аркадьевич \\ магистрант \\ Бараков Тимур Вадимович \\ студент \\ Научный руководитель: Ханиева И.М. \\ доктор с.х. наук, профессор \\ ФГБОУ ВО Кабардино-Балкарский ГАУ
}

Аннотация: В статье приведены результаты исследований по продуктивности и качеству сортов картофеля в зависимости от макроудобрений и густоты посадки.

Ключевые слова: Картофель, сорта, густота посадки, макроудобрения, урожайность, показатели качества.

Безконтрольное использование химических средств для интенсификации сельскохозяйственного производства с целью обеспечения максимальной биопродуктивности в конечном счете несовместимо с сохранением нормальной среды обитания человека.

Данная проблема может быть решена с переходом на интегрированное земледелие. Она должна базироваться на применение биологических, селекционных, агротехнических и технических приемов, дополняемых химическими средствами защиты лишь при условии обязательного учета экономических порогов вредоносности. [1].В последние годы из-за прогрессирующей экологической нагрузки на почву, в целом значительно 
ухудшились показатели качества (нитраты, крахмалистость клубней, содержание витамина «С», белок, сухое вещество и пр.).

В 2019 -2021 гг. в УПК ФГБОУ ВО Кабардино-Балкарский ГАУ, проводились исследования по изучению реакции сортов картофеля на макроудобрения в условиях различной густоты посадки. Проводилась оценка показателей качества в зависимости от изучаемых факторов.

В опыте использована традиционная общепринятая технология картофеля в Кабардино-Балкарии. По фазам вегетации проводили учеты, наблюдения. Определяли наступления морфологических и фенологических фаз развития растений.

Среди природных и агротехнических факторов, способствующих повышению эффективности удобрений, увеличению урожайности и улучшению качества продукции, большая роль принадлежит сорту. Урожайные данные, приведенные в течение, дают конкретную характеристику отзывчивости различных сортов на минеральное питание (фона удобрений) и густоту посадки. Отзывчивость разных сортов на густоту посадки и внесение минеральных удобрений изменяются в зависимости от группы спелости, сорта, их индивидуальных особенностей, метеорологических условий года.

В среднем за годы исследований при увеличении густоты посадки растений по сорту Горянка прибавка урожайности составила $-2,7-4,1$ т/га, при повышении уровня минерального питания до N120P150К120 - 3,46,4 т/га. Эффективность и наибольший прирост урожайности исследуемых сортов составили: Нарт-1 -4,8 -13,9; 3,2-11,9 т/га; Нальчикский - 2,6-5,8; 2,44,6 т/га, Зольский - 5,7 - 9,3; 2,3-7,4 т/га; Мусинский - 3,7-5,8; 6,6-7,8 т/га.

Самая высокая прибавка (2019 г.) урожая у сорта Горянка сформирована (относительно густоты - 23 тыс. шт./га и дозы удобрений:N60P90К60) в варианте густоты посадки 80 тыс. шт./га, минерального питания N120P150К120 - 12 т/га, 2019 г. -11,4 т/га, в остальных вариантах опыта следующие результаты: Нарт-12,6 т/га, Нальчикский 15,3 т/га, Зольский - 19,6 т/га, Мусинский - 12,2 т/га.

К основным показателем качества клубней картофеля относятся нитраты, крахмалистость, витамин «С», белок, сухое вещество и т.д. (табл. 1) 
Таблица 1

Урожайность и качество сортов картофеля в зависимости от норм минерального питания и густоты посадки (2019-2021 гг.)

\begin{tabular}{|c|c|c|c|c|c|c|c|c|}
\hline \multirow{2}{*}{$\begin{array}{ll}0 \\
0 \\
0 \\
0\end{array}$} & \multirow{2}{*}{$\begin{array}{c}\text { Фон } \\
\text { питания } \\
\text { В }\end{array}$} & \multirow{2}{*}{$\begin{array}{c}\text { Густота } \\
\text { посадки } \\
\text { тыс./га } \\
\text { С }\end{array}$} & $\begin{array}{l}\text { Урожай- } \\
\text { ность, } \\
\text { т/га }\end{array}$ & $\begin{array}{c}\text { Нитраты } \\
\text { мг/кг } \\
\text { сырых } \\
\text { клубней }\end{array}$ & $\begin{array}{c}\text { Белок, } \\
\%\end{array}$ & $\begin{array}{c}\text { Витамин } \\
\text { « », } \\
\%\end{array}$ & $\begin{array}{c}\text { Крахмал } \\
\%\end{array}$ & $\begin{array}{c}\text { Cyxoe } \\
\text { B-вo, } \\
\%\end{array}$ \\
\hline & & & $\mathrm{y}$ & $\mathrm{H}$ & Б & B & K & $\mathrm{C}$ \\
\hline \multirow{3}{*}{ 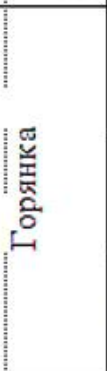 } & $\mathrm{N}_{60} \mathrm{P}_{90 \mathrm{~K}} 60$ & $\begin{array}{l}23 \\
47 \\
80\end{array}$ & $\begin{array}{l}16,3 \\
16,2 \\
18,0\end{array}$ & $\begin{array}{l}109,6 \\
106,3 \\
111,9\end{array}$ & 2,0 & $\begin{array}{l}138 \\
147 \\
146\end{array}$ & $\begin{array}{l}15,8 \\
15,9 \\
16,0\end{array}$ & $\begin{array}{l}21,4 \\
21,7 \\
21,8\end{array}$ \\
\hline & $\mathrm{N}_{90} \mathrm{P}_{120 \mathrm{~K}} 90$ & $\begin{array}{r}23 \\
47 \\
80^{-}\end{array}$ & $\begin{array}{l}17,0 \\
19,7 \\
21,0\end{array}$ & $\begin{array}{l}169,2 \\
154,6 \\
154,1\end{array}$ & 2,0 & $\begin{array}{l}135 \\
134 \\
155\end{array}$ & $\begin{array}{l}15,7 \\
15,5 \\
16,1\end{array}$ & $\begin{array}{l}21,6 \\
21,3 \\
21,9\end{array}$ \\
\hline & $\mathrm{N}_{120} \mathrm{P}_{150 \mathrm{~K}} 120$ & $\begin{array}{l}23 \\
47 \\
80\end{array}$ & $\begin{array}{l}23,0 \\
26,9 \\
28,4\end{array}$ & $\begin{array}{l}170,2 \\
141,4 \\
168,2\end{array}$ & 2,1 & $\begin{array}{l}123 \\
128 \\
134\end{array}$ & $\begin{array}{l}15,1 \\
14,8 \\
14,7\end{array}$ & $\begin{array}{l}20,8 \\
20,6 \\
20,5\end{array}$ \\
\hline \multirow{3}{*}{ 悹 } & $\mathrm{N}_{60} \mathrm{P}_{90} \mathrm{~K}_{60}$ & $\begin{array}{l}23 \\
47 \\
80\end{array}$ & $\begin{array}{l}18,8 \\
23,6 \\
25,8\end{array}$ & $\begin{array}{l}108,5 \\
162,2 \\
117,3\end{array}$ & 2,2 & $\begin{array}{l}168 \\
180 \\
192\end{array}$ & $\begin{array}{l}15,6 \\
16,1 \\
16,6\end{array}$ & $\begin{array}{l}21,4 \\
21,5 \\
22,2\end{array}$ \\
\hline & $\mathrm{N}_{90} \mathrm{P}_{120} \mathrm{~K}_{90}$ & $\begin{array}{l}23 \\
47 \\
80 \\
\end{array}$ & $\begin{array}{l}22,0 \\
28,3 \\
31,3 \\
\end{array}$ & $\begin{array}{l}117,0 \\
113,3 \\
132,9 \\
\end{array}$ & 2,2 & $\begin{array}{l}165 \\
172 \\
178 \\
\end{array}$ & $\begin{array}{l}15,3 \\
15,2 \\
15,4 \\
\end{array}$ & $\begin{array}{l}21,2 \\
21,0 \\
21,1 \\
\end{array}$ \\
\hline & $\mathrm{N}_{120} \mathrm{P}_{150 \mathrm{~K}} 120$ & $\begin{array}{l}23 \\
47 \\
80\end{array}$ & $\begin{array}{l}23,8 \\
30,5 \\
37,7\end{array}$ & $\begin{array}{l}144,3 \\
141,8 \\
133,7\end{array}$ & 2,1 & $\begin{array}{l}153 \\
163 \\
166\end{array}$ & $\begin{array}{l}15,0 \\
14,8 \\
15,2\end{array}$ & $\begin{array}{l}20,7 \\
20,6 \\
21,0\end{array}$ \\
\hline \multirow{3}{*}{ 茎 } & $\mathrm{N}_{60} \mathrm{P}_{90 \mathrm{~K}} 60$ & $\begin{array}{l}23 \\
47 \\
80\end{array}$ & $\begin{array}{l}14,7 \\
17,3 \\
20,7\end{array}$ & $\begin{array}{c}87,2 \\
80,7 \\
102,1\end{array}$ & 2,2 & $\begin{array}{l}169 \\
164 \\
178\end{array}$ & $\begin{array}{l}19,6 \\
19,8 \\
20,1\end{array}$ & $\begin{array}{l}25,4 \\
25,6 \\
25,5\end{array}$ \\
\hline & $\mathrm{N}_{90} \mathrm{P}_{120} \mathrm{~K}_{90}$ & $\begin{array}{l}23 \\
47 \\
80\end{array}$ & $\begin{array}{l}17,1 \\
21,9 \\
22,6\end{array}$ & $\begin{array}{l}111,4 \\
105,1 \\
108,5\end{array}$ & 2,2 & $\begin{array}{l}157 \\
158 \\
176\end{array}$ & $\begin{array}{l}19,5 \\
20,1 \\
20,2\end{array}$ & $\begin{array}{l}25,5 \\
26,2 \\
25,9\end{array}$ \\
\hline & $\mathrm{N}_{120} \mathrm{P}_{150 \mathrm{~K}} 120$ & $\begin{array}{l}23 \\
47 \\
81\end{array}$ & $\begin{array}{l}19,7 \\
24,4 \\
25,5\end{array}$ & $\begin{array}{l}117,8 \\
125,4 \\
115,4\end{array}$ & 2,2 & $\begin{array}{l}145 \\
142 \\
171\end{array}$ & $\begin{array}{l}18,4 \\
19,8 \\
19,2\end{array}$ & $\begin{array}{l}24,1 \\
24,7 \\
25,0\end{array}$ \\
\hline \multirow{3}{*}{ 站 } & $\mathrm{N}_{60} \mathrm{P}_{90 \mathrm{~K}} 60$ & $\begin{array}{l}23 \\
47 \\
80\end{array}$ & $\begin{array}{l}14,9 \\
20,6 \\
23,0\end{array}$ & $\begin{array}{r}91,1 \\
106,9 \\
116,7\end{array}$ & 2,23 & $\begin{array}{l}195 \\
134 \\
212\end{array}$ & $\begin{array}{l}17,3 \\
18,1 \\
17,8\end{array}$ & $\begin{array}{l}23,3 \\
23,8 \\
23,7\end{array}$ \\
\hline & $\mathrm{N}_{90} \mathrm{P}_{120 \mathrm{~K}} 90$ & $\begin{array}{l}23 \\
47 \\
80\end{array}$ & $\begin{array}{l}18,1 \\
23,3 \\
25,3\end{array}$ & $\begin{array}{c}117,1 \\
95,6 \\
150,3\end{array}$ & 2,3 & $\begin{array}{l}188 \\
189 \\
191\end{array}$ & $\begin{array}{l}16,6 \\
17,1 \\
16,6\end{array}$ & $\begin{array}{l}23,4 \\
22,9 \\
22,3\end{array}$ \\
\hline & $\mathrm{N}_{120} \mathrm{P}_{150 \mathrm{~K}_{120}}$ & $\begin{array}{l}23 \\
47 \\
80\end{array}$ & $\begin{array}{l}21,1 \\
25,5 \\
30,4\end{array}$ & $\begin{array}{l}123,2 \\
144,7 \\
161,5\end{array}$ & 2,2 & $\begin{array}{l}170 \\
176 \\
177\end{array}$ & $\begin{array}{l}16,3 \\
16,2 \\
16,4\end{array}$ & $\begin{array}{l}21,4 \\
21,9 \\
23,3\end{array}$ \\
\hline \multirow{4}{*}{ 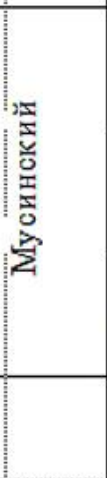 } & $\mathrm{N}_{60} \mathrm{P}_{90 \mathrm{~K}} 60$ & $\begin{array}{l}23 \\
47 \\
80\end{array}$ & $\begin{array}{l}16,1 \\
20,9 \\
21,5\end{array}$ & $\begin{array}{l}73,7 \\
87,1 \\
66,0\end{array}$ & 2,1 & $\begin{array}{l}169 \\
213 \\
210\end{array}$ & $\begin{array}{l}19,9 \\
20,0 \\
20,4\end{array}$ & $\begin{array}{l}23,4 \\
26,0 \\
26,1\end{array}$ \\
\hline & $\mathrm{N}_{90} \mathrm{P}_{120} \mathrm{~K}_{90}$ & $\begin{array}{l}23 \\
47 \\
80\end{array}$ & $\begin{array}{l}20,1 \\
23,8 \\
24,6\end{array}$ & $\begin{array}{l}93,1 \\
81,7 \\
90,3\end{array}$ & 2,2 & $\begin{array}{l}170 \\
168 \\
198 \\
\end{array}$ & $\begin{array}{l}19,4 \\
19,1 \\
19,0\end{array}$ & $\begin{array}{l}25,1 \\
25,1 \\
24,5\end{array}$ \\
\hline & $\mathrm{N}_{120} \mathrm{P}_{150 \mathrm{~K}_{12}}$ & $\begin{array}{l}23 \\
47 \\
80\end{array}$ & $\begin{array}{l}22,8 \\
28,6 \\
33,1\end{array}$ & $\begin{array}{c}96,7 \\
96,3 \\
111,8\end{array}$ & 2,2 & $\begin{array}{l}163 \\
161 \\
185\end{array}$ & $\begin{array}{l}17,2 \\
18,4 \\
18,7\end{array}$ & $\begin{array}{l}23,2 \\
24,3 \\
24,4\end{array}$ \\
\hline & $\begin{array}{l}\text { A } \\
\text { B } \\
\text { C }\end{array}$ & $\mathrm{HCP}_{0.5}$ & $\begin{array}{l}3,3 \\
0,9 \\
1,4\end{array}$ & $\begin{array}{c}29,7 \\
7,7 \\
13,3\end{array}$ & $\begin{array}{l} \\
-\end{array}$ & $\begin{array}{l}1,3 \\
0,3 \\
0,6\end{array}$ & $\begin{array}{l}0,9 \\
0,2 \\
0,4\end{array}$ & $\begin{array}{l}1,9 \\
0,5 \\
0,8\end{array}$ \\
\hline
\end{tabular}


Качество клубней зависит от многих факторов : погодные условия года, повышенные дозы органических и минеральных удобрений, сроки посадки, и индивидуальные особенности сорта, поражение ботвы фитофторозом, густота посадки, несбалансированность питания, способы удаления ботвы, время определения нитратов (днем или ночью). Полученные результаты свидетельствуют о неравнозначном влиянии факторов, определяющих показатели качества продукции $[3,4,5,6$.$] .$

Правильное применение удобрений должно улучшать или по крайней мере не ухудшать биологическое качество растениеводческой продукции с повышением урожайности картофеля. В среднем по годам исследований фактор густоты посадки не оказывал существенного влияния на накопления нитратов в продукции. Повышение доз минерального питания приводило к заметному изменению биохимического состава клубней. Наибольшее количество нитратов накапливалось у раннего сорта Горянка, 109,6168,2 мг/кг сырой массы, наименьшее у.е. - Мусинский 73,7-111,8 мг/кг сырой массы. В целом, наименьшее количество $(\mathrm{NO} 3)$ накоплено в клубнях урожая 2019 г., при нормах питания N60P90К60 - N90P120K90 - 180,7-201 мг/кг сырой массы. Наибольшее - $\quad$ в 2020-2021 гг., $\quad$ не превышающая предельно допустимых концентраций (ПДК). Содержание витамина «С» снижалось в продукции по мере возрастания доз удобрений - 0,3-5,2 мг \%. И наоборот, с повышением густоты посадки, увеличивалось содержание витамина «С» от 0,9-до 2,8 мг\% в зависимости от сорта. Концентрация сухого вещества и крахмала изменились с повышением доз минеральных дозудобрений.

Увеличение густоты посадки картофеля сопровождалось повышением крахмалистости клубней на 0,1-1,5 \% в зависимости от сорта и нормы питания. А при повышении уровня минерального питания происходило снижение крахмалистости клубней в среднем за 3 года на 0,1-2,7\%, а сухого вещества на 0,2-1,7\% в зависимости от анализируемых сортов.

Наличие белка в клубнях картофеля также зависело от густоты посадки картофеля и количества вносимых удобрений.

\section{Список литературы}

1. Абидов Х.К., Особенности семеноводства картофеля в КБР/Абидов Х.К., Ханиева И.М., Абидова Г.Х., Одижев А.А.//В сборнике: Перспективные 
инновационные проекты молодых ученых. Материалы VIII Всероссийской конференции студентов, аспирантов и молодых ученых. 2021. С. 134-138.

2. Басиев С.С., Способ стимуляции роста меристемных растений картофеля in vitro/ Басиев С.С., Бекузарова С.А., Ханиева И.М., и др.//Патент на изобретение RU $2599556 \mathrm{C} 1, \quad 10.10 .2016$. Заявка № 2015123457/13 от 15.06.2015.

3. Букасов С.М. Селекция и семеноводство картофеля/ Букасов С.М., Камераз А.Я.// Ленинград. Изд. «Колос», 1972-360 с.

4. Закладка опытов, полевые и лабораторные исследования проведены по общепринятым и утвержденным методикам. Новые технологии производства оздоровленного исходного материала в элитном семеноводстве картофеля, Москва-2000 г, Мусинский, С.М. Бойко, Анисимов Б.В., Симаков и др. Москва, 2010 г. С. 28.

5. Кишев А.Ю. Эффективность микроэлементов в земледелии/ Кишев А.Ю., Ханиева И.М., Жеруков Т.Б., Шибзухов 3.С.//Аграрная Россия. 2019. № 1. С. 19-23.

6. Магомедов К.Г. Восстановитель плодородия почв/ Ханиева И.М., Кишев А.Ю., Бозиев А.Л., Жеруков Т.Б., Шибзухов 3.С., Амшоков А.Э. //News of Science and Education. 2017. T. 11. № 3.

7. Ханиева И.М., Способ стимуляции роста и развития растений Ханиева И.М., Бекузарова С.А., Дулаев Т.А., и др.//Патент на изобретение RU 2708325 C1, 05.12.2019. Заявка № 2018143251 от 06.12.2018. 